e ISSN-0976-6855 | Visit us : www.researchjournal.co.in

\title{
Antifungal activity of actinomycetes against wilt and dry root rot diseases of redgram [Cajanus cajan (L.) Millsp.]
}

\author{
S. Malathi
}

Horticultural Research Station (T.N.A.U.) Ooty (T.N.) India

\section{ARITCLE INFO}

Received : 08.08 .2018

Revised : 12.09 .2018

Accepted : 25.09.2018

KEY WORDS :

Redgram - Fusarium udum,

Macrophomina phaseolina,

Actinomycetes, Antifungal activity

*Corresponding author:

malathi_agri@rediffmail.com

\begin{abstract}
Actinomycetes isolates were collected from different redgram growing areas of Tamil Nadu and they were tested for their antagonistic activity against Fusarium udum and Macrophomina phaseolina. Among the tested isolates of Actinomycetes AC (5) reported highest 82.85 per cent reduction of mycelial growth of Fusarium udum and 85.13 per cent reduction of mycelial growth of Macrophomina phaseolina under in vitro condition.
\end{abstract}

How to view point the article : Malathi, S. (2018). Antifungal activity of actinomycetes against wilt and dry root rot diseases of redgram [Cajanus cajan (L.) Millsp.]. Internat. J. Plant Protec., 11(2) : 169-173, DOI : 10.15740/HAS/IJPP/11.2/169-173, Copyright@ 2018: Hind Agri-Horticultural Society. 